\title{
Penerapan Model Pembelajaran Team Games Tournament untuk Meningkatkan Hasil Belajar Siswa pada Mata Pelajaran Perencanaan dan Instalasi Sistem Audio Video di SMK Negeri 4 Gowa
}

\author{
Rafiuddin \\ SMK Negeri 4 Gowa, Kabupaten Gowa Provinsi Sulawesi Selatan \\ Corresponding Author. Email: rafiuddin@gmail.com
}

\begin{abstract}
This study aims to improve students' learning outcomes of Audio Video System Planning and Installation by applying the Team Games Tournament learning model in class XI TAV1 SMK Negeri 4 Gowa. The type of research used is classroom action research, using the Kemmis \& McTaggart model which consists of four stages: planning, implementing, observing and reflecting. The four stages are carried out in two cycles. The subjects in this study were 33 people in class XI TAV1. The instrument used was a test of learning outcomes and student observation sheet instruments. The collected data were then analyzed using descriptive statistical analysis. The results showed that the application of the Team Games Tournament learning model could improve student learning outcomes. This is evident from the increasing learning outcomes of students. Based on the results of the study, it can be concluded that of the 33 students, more than $85 \%$ have completed their studies in the subject of Planning and Installation of Audio Video Systems with the KKM standard, namely 75 .
\end{abstract}

\begin{abstract}
Abstrak: Penelitian ini bertujuan untuk meningkatkan hasil belajar Perencanaan dan Instalasi Sistem Audio Video siswa dengan mengaplikasikan model pembelajaran Team Games Tournament di kelas XI TAV1 SMK Negeri 4 Gowa. Jenis penelitian yang digunakan adalah penelitian tindakan kelas model Kemmis \& McTaggart yang terdiri dari empat tahapan yaitu: perencanaan, pelaksanaan, observasi dan refleksi. Subjek dalam penelitian ini adalah kelas XI TAV1 yang berjumlah 33 orang. Instrumen yang digunakan adalah tes hasil belajar serta lembar pengamatan siswa. Data yang terkumpul kemudian dianalisis menggunakan analisis statistik deskriptif. Hasil penelitian menunjukkan bahwa pengaplikasian model pembelajaran Team Games Tournament dapat meningkatkan hasil belajar siswa. Hal ini terbukti dari perolehan hasil belajar siswa yang terus meningkat. Berdasarkan hasil penelitian dapat disimpulkan bahwa dari 33 siswa lebih dari $85 \%$ telah tuntas belajarnya pada mata pelajaran Perencanaan dan Instalasi Sistem Audio Video dengan standar KKM yaitu 75.
\end{abstract}

How to Cite: Rafiuddin, R. (2021). Penerapan Model Pembelajaran Team Games Tournament untuk Meningkatkan Hasil Belajar Siswa pada Mata Pelajaran Perencanaan dan Instalasi Sistem Audio Video di SMK Negeri 4 Gowa. Jurnal Paedagogy, 8(1). doi:https://doi.org/10.33394/jp.v8i1.3103

\section{Pendahuluan}

Banyak yang beranggapan bahwa rendahnya kualitas pendidikan saat ini berhubungan dengan rendahnya aktivitas belajar kooperatif siswa, yaitu bagaimana cara siswa itu belajar bersama dengan temannya untuk memahami suatu materi pembelajaran. Menurut Qadriyah (2002) rendahnya aktivitas belajar kooperatif tersebut juga diakibatkan oleh kurang efektifnya metode pembelajaran yang diterapkan oleh guru. Setiap proses pembelajaran, seorang guru menyadari keaktivan membutuhkan keterlibatan siswa secara langsung agar siswa memiliki pengalaman. Sehubungan dengan itu, guru harus merancang kegiatan pembelajaran yang lebih banyak pada pembelajaran individual dan kelompok kecil. Didalam kelompok kecil siswa akan mendiskusikan masalah-masalah, diantaranya menyelesaikan 
soal-soal latihan untuk memperdalam pemahaman mereka tentang konsep materi yang diajarkan (Wirejati, 2019; Yuliati, 2018; Suryani, 2018). Rendahnya aktifitas siswa dimungkinkannya karena guru hanya menggunakan metode ceramah, sehingga banyak siswa yang sulit memahami konsep yang dijelaskan oleh guru, siswa merasa segan, malu, bahkan takut untuk bertanya kepada guru (Fajuri, 2019; Roshida, 2020; Setiarini, 2016).

Pelaksanaan pembelajaran di sekolah seringkali dihadapkan pada masalah yang berkaitan dengan kualitas pembelajaran. Kualitas pembelajaran bergantung pada kemampuan guru dalam menyiapkan kegiatan pembelajaran yang baik. Peran siswa juga sangat penting dalam menentukan pencapaian tujuan pembelajaran, terutama partisipasi aktifnya dalam proses belajar di kelas. Namun, jika siswa tidak termotivasi dengan baik maka tujuan yang ingin dicapai tidak akan terwujud. Hal itulah yang sekarang menjadi tantangan profesionalisme guru, untuk meningkatkan kualitas pembelajaran, guru diharapkan dapat merancang pengalaman belajar dan memilih model pembelajaran yang sesuai dengan karakteristik materi dan tujuan pembelajaran. Kurangnya pemahaman guru terhadap konsep pembelajaran yang tepat untuk meningkatkan kualitas pembelajaran di kelas berdampak pula terhadap kurangnya minat belajar siswa yang secara otomatis mempengaruhi hasil belajar siswa menjadi rendah. Hasil belajar menurut Sugandi (2008) adalah merupakan refleksi keleluasaan, kedalaman, dan kekompleksitasan yang digambarkan secara jelas serta dapat diukur dengan teknik penilaian tertentu. Untuk mengetahui seberapa penyampaian hasil belajar yang diperoleh individu (siswa) harus dilakukan suatu penilaian. Sedang menurut Sudjana (2004), hasil belajar adalah kemampuan-kemampuan yang dimiliki siswa setelah ia menerima pengalaman belajar.

Model pembelajaran Teams Games Tournament (TGT) adalah salah satu tipe atau model pembelajaran kooperatif yang mudah diterapkan, melibatkan aktivitas seluruh siswa tanpa harus ada perbedaan status, melibatkan peran siswa sebagai tutor sebaya dan mengandung unsur permainan dan reinforcement. Aktivitas belajar dengan permainan yang dirancang dalam pembelajaran kooperatif model Teams Games Tournament (TGT) memungkinkan siswa dapat belajar lebih rileks disamping menumbuhkan tanggung jawab, kejujuran, kerja sama, persaingan sehat dan keterlibatan belajar. Team Games Tournament (TGT) menggunakan turnamen untuk menggantikan kuis, di mana siswa memainkan game di meja turnamen dengan yang lain untuk menyumbangkan poin bagi skor timnya. Sebuah prosedur "menggeser kedudukan" membuat permainan ini cukup adil (Sri Pertiwi, 2011). Menurut Rusman (2012), langkah-langkah pembelajaran kooperatif yang terdiri atas 6 tahap:

Tabel 1. Langkah - Langkah Pembelajaran Kooperatif

\begin{tabular}{|l|l|}
\hline \multicolumn{1}{|c|}{ Tahap } & \multicolumn{1}{|c|}{ Kegiatan Guru } \\
\hline $\begin{array}{l}\text { Tahap 1 } \\
\text { Menyampaikan tujuan dan } \\
\text { motivasi siswa }\end{array}$ & $\begin{array}{l}\text { Guru menyampaikan tujuan pembelajaran yang akan dicapai } \\
\text { pada kegiatan pelajaran dan menekankan topic yang akan } \\
\text { dipelajari dan memotivasi siswa belajar. }\end{array}$ \\
\hline $\begin{array}{l}\text { Tahap 2 } \\
\text { Menyajikan Informasi }\end{array}$ & $\begin{array}{l}\text { Guru menyajikan informasi atau materi kepada siswa dengan } \\
\text { jalan demonstrasi atau melalui bahan bacaan. }\end{array}$ \\
\hline $\begin{array}{l}\text { Tahap 3 } \\
\text { Mengorganisasi siswa } \\
\text { kedalam kelompok- } \\
\text { kelompok belajar }\end{array}$ & $\begin{array}{l}\text { Guru menjelaskan kepada siswa bagaimana caranya } \\
\text { membentuk kelompok belajar dan membimbing setiap } \\
\text { kelompok agar melakukan transisi secara efektif dan efisien. }\end{array}$ \\
\hline Tahap 4 & Guru membimbing kelompok-kelompok belajar pada saat \\
\hline
\end{tabular}




\begin{tabular}{|l|l|}
\hline $\begin{array}{l}\text { Membimbing kelompok } \\
\text { bekerja dan belajar }\end{array}$ & mereka mengerjakan tugas mereka. \\
\hline $\begin{array}{l}\text { Tahap 5 } \\
\text { Evaluasi }\end{array}$ & $\begin{array}{l}\text { Guru mengevaluasi hasil belajar tentang materi yang telah } \\
\text { dipelajari atau masing-masing kelompok mempresentasikan } \\
\text { hasil kerjanya. }\end{array}$ \\
\hline $\begin{array}{l}\text { Tahap 6 } \\
\text { Memberikan penghargaan }\end{array}$ & $\begin{array}{l}\text { Guru mencari cara-cara untuk menghargai baik upaya } \\
\text { maupun hasil belajar individu dan kelompok. }\end{array}$ \\
\hline
\end{tabular}

Berdasarkan hasil observasi awal yang diperoleh, siswa kelas XI TAV 1 di SMK Negeri 4 Gowa masih memiliki semangat yang relatif rendah dalam mengikuti pelajaran Perencanaan dan Instalasi Sistem Audio Video dilihat dari kurangnya partisipasi aktif siswa selama proses belajar mengajar berlangsung sehingga proses pembelajaran masih berorintasi teaching center. Dalam hal ini terjadi karena proses pembelajarannya yang kurang efektif dan tidak menyenangkan sehingga siswa jenuh berada di dalam kelas. Penggunaan model pembelajaran yang kurang tepat terhadap konsep pembelajaran oleh guru mata pelajaran merupakan salah satu faktor penyebab proses pembelajaran jadi kurang efektif dan tidak menarik.

Pembelajaran yang menyenangkan dapat diterapkan model TGT dalam proses belajar mengajar yang merupakan model pembelajaran inovatif dan membantu siswa agar dapat lebih mengeksplorasi pengetahuan mereka. Sehingga siswa mempunyai peran penting, sedangkan guru sebagai penyedia sumber dan alat bantu belajar sebagai motivator bagi siswa. Adapun tujuan dari penelitian ini adalah untuk meningkatkan hasil belajar Perencanaan dan Instalasi Sistem Audio Video siswa dengan mengaplikasikan model pembelajaran Team Games Tournament di kelas XI TAV 1 SMK Negeri 4 Gowa.

\section{Metode Penelitian}

Metode penelitian yang digunakan dalam penelitian ini adalah penelitian tindakan kelas (classroom action research). Desain penelitian mengacu pada model Kemmis dan MC Taggart yang terdiri dari 4 kompenen yaitu perencanaan, tindakan, observasi, dan refleksi. Keempat komponen yang berupa untaian tersebut dipandang sebagai satu siklus. Pada gambar berikut menjelaskan bahwa didalamnya terdiri dari dua perangkat komponen yang dapat dikatakan sebagai dua siklus. Untuk pelaksanannnya, jumlah siklus sangat bergantung kepada permasalahan yang perlu diselesaikan.

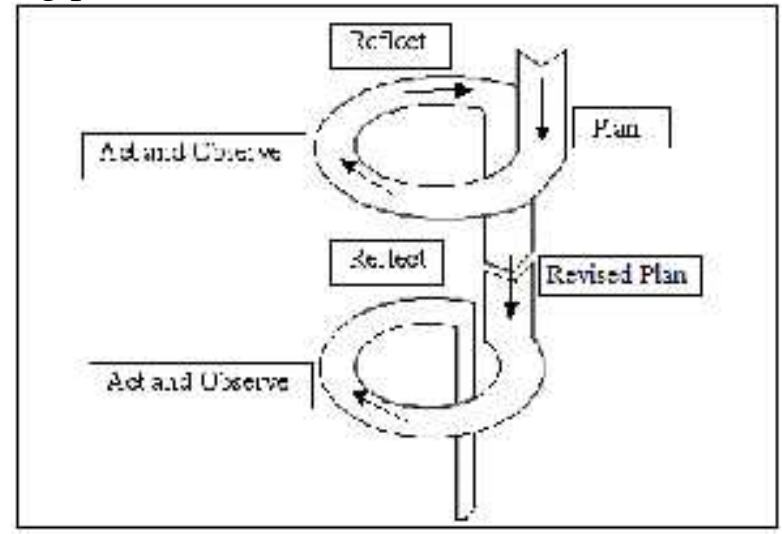

Gambar 1. Desain siklus PTK menurut Kemmis \& Mc Taggart 
Subjek penelitian tindakan kelas ini adalah seluruh siswa kelas XI TAV 1 di SMK Negeri 4 Gowa pada semester ganjil tahun pelajaran 2019/2020, dengan jumlah 33 siswa yang terdiri dari 32 siswa laki-laki dan 1 siswa perempuan. Pelaksanaan penelitian ini dilakukan dalam dua siklus, yaitu siklus I dan siklus II yang merupakan rangkaian kegiatan yang saling berkaitan. Pada siklus I dilakukan 4 kali pertemuan, begitupun siklus II dengan satu kali tes setiap akhir siklus. Pelaksanaan penelitian dilakukan karena adanya permasalahan yang dialami dalam pembelajaran. Kemudian dilakukan perencanaan tindakan, untuk mengatasi permasalahan tersebut, yang dilanjutkan dengan upaya pelaksanaan tindakan dan observasi pelaksanaan. Hasil observasi dan hasil belajar selanjutnya direfleksi unutk mengetahui hasil pelaksanaan tindakan. Untuk lebih jelasnya berikut adalah gambar alur penelitian tindakan kelas.

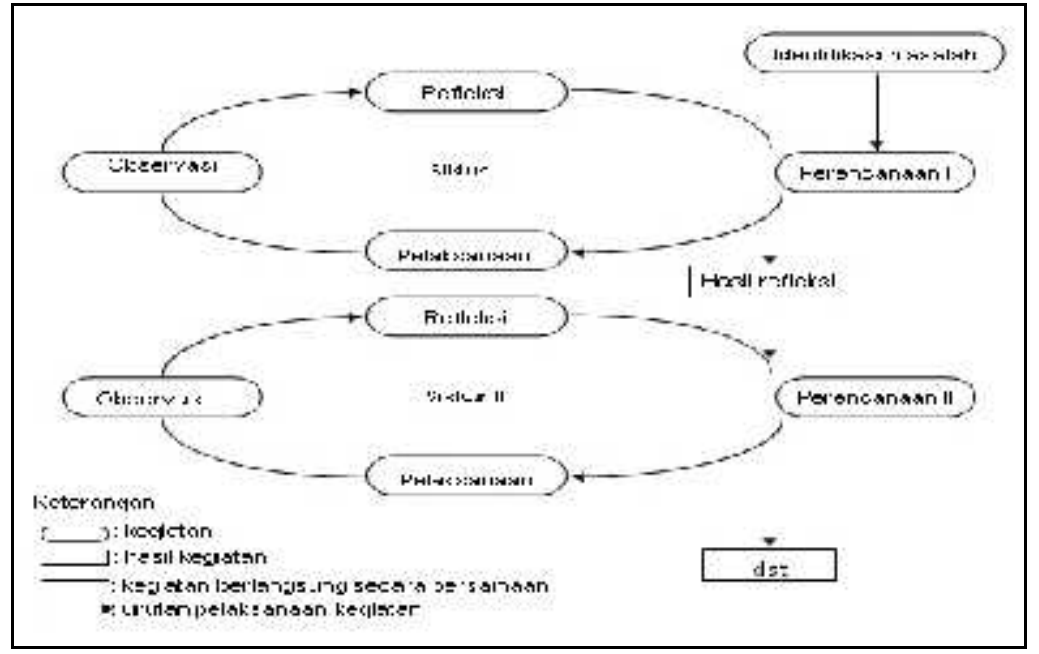

Gambar 2. Alur penelitian tindakan kelas

Instrumen yang digunakan dalam penelitian ini dalah tes, observasi atau pengamatan dan dokumentasi. Data yang diperoleh dari hasil pengamatan perilaku dan tanggapan siswa selanjutnya dianalisis secara kualitatif, sedangkan data hasil belajar siswa dianalisis secara kuantitatif dengan menggunakan statistic deskriptif.

$$
\text { Nilai }=\frac{\text { skor yang diperoloh }}{\text { skor maksimum }} \times 100 \%
$$

Berdasarkan hasil tes yang dianalisis adalah skor perolehan siswa yang telah diubah kebentuk persentase. Untuk keperluan analisis, disusun pula suatu kategori yang menandakan antara syarat siswa yang dikatakan meningkatkan hasil belajarnya sesuai ketercapaian yang diharapkan. Adapun kriteria secara deskriptif yang digunakan setelah sampai pada persentase adalah berdasarkan teknik kategorisasi standar yang ditetapkan oleh Departemen Pendidikan Nasional (Nadira, 2013) sebagai berikut.

\section{Tabel 2. Pedoman Kategori Hasil Belajar Siswa}

\begin{tabular}{|c|c|c|}
\hline No & Skor & Kategori \\
\hline 1 & $90-100$ & Sangat tinggi \\
\hline 2 & $80-89$ & Tinggi \\
\hline 3 & $65-79$ & Sedang \\
\hline 4 & $55-64$ & Rendah \\
\hline 5 & $0-54$ & Sangat rendah \\
\hline
\end{tabular}


Indikator keberhasilan penelitian tindakan kelas ini adalah apabila terjadi peningkatan hasil belajar pada mata pelajaran Perencanaan dan Instalasi Sistem Audio Video dan keaktifan siswa mengikuti pelajaran serta terjadinya peningkatan skor yang diperoleh siswa setelah melaksanakan proses pembelajaran dengan menggunakan pembelajaran kooperatif tipe Team Games Tournament (TGT). Indikator keberhasilan dalam penelitian ini adalah jika setiap siswa dikatakan tuntas belajarnya (ketuntasan individu) sesuai dengan Kriterian Ketuntasan Minimal (KKM) yaitu dengan nilai $\geq 75$, dan menurut depdikbud (dalam Trianto, 2010: 241), suatu kelas dikatakan tuntas belajarnya (ketuntasan klasikal) jika dalam kelas tersebut terdapat $\geq 85 \%$ siswa yang telah tuntas belajarnya.

\section{Hasil Penelitian dan Pembahasan \\ Deskripsi Hasil Siklus I}

Sebelum pelaksanaan tindakan kelas menggunakan model pembelajaran team games tournament pada siklus I, terlebih dahulu peneliti menyusun rencana pembelajaran. Pembelajaran yang dilaksanakan berpedoman pada rencana pembelajaran yang telah disusun yaitu selama 2 kali pertemuan (6x45 menit). Pelaksanaan tindakan kelas dilakukan oleh guru mata pelajaran Perencanaan dan Instalasi Sistem Audio Video, dan di observasi oleh rekan peneliti.

1) Aktivitas Siswa

Data observasi aktivitas siswa diperoleh dari lembar observasi selama proses belajar mengajar berlangsung pada setiap pertemuan yang dilakukan oleh observer. Penilaian aktivitas siswa yang diamati sebanyak 10 komponen yang dapat dilihat pada tabel 4.1 berikut:

Tabel 3. Hasil Observasi Aktivitas Siswa Pada Siklus I

\begin{tabular}{|c|c|c|c|c|c|c|c|c|c|c|c|}
\hline \multirow{3}{*}{ No } & \multirow{3}{*}{$\begin{array}{c}\text { Indikator yang } \\
\text { Diamati }\end{array}$} & \multicolumn{8}{|c|}{ Siklus I } & \multirow{3}{*}{$\begin{array}{c}\text { Rata } \\
\text { - rata }\end{array}$} & \multirow{3}{*}{$\begin{array}{c}\text { Rata- } \\
\text { rata } \\
(\%)\end{array}$} \\
\hline & & \multicolumn{2}{|c|}{ Pert-1 } & \multicolumn{2}{|c|}{ Pert-2 } & \multicolumn{2}{|c|}{ Pert-3 } & \multicolumn{2}{|c|}{ Pert-4 } & & \\
\hline & & $\mathbf{f}$ & $\%$ & $\mathbf{F}$ & $\%$ & $\mathbf{f}$ & $\%$ & $\mathbf{f}$ & $\%$ & & \\
\hline 1 & Hadir tepat waktu & 33 & 100 & 31 & 95,24 & 30 & 90,48 & 27 & 80,95 & 30 & $91,67 \%$ \\
\hline 2 & $\begin{array}{l}\text { Memperhatikan } \\
\text { guru menjelaskan }\end{array}$ & 13 & 38,10 & 20 & 61,90 & 19 & 57,14 & 25 & 76,19 & 19 & $58,33 \%$ \\
\hline 3 & Bertanya & 3 & 9,52 & 5 & 14,29 & 5 & 14,29 & 9 & 28,57 & 6 & $16,67 \%$ \\
\hline 4 & $\begin{array}{l}\text { Aktif dalam } \\
\text { diskusi }\end{array}$ & 8 & 23,81 & 16 & 47,62 & 16 & 47,62 & 19 & 57,14 & 15 & $44,05 \%$ \\
\hline 5 & $\begin{array}{l}\text { Menghargai } \\
\text { pendapat }\end{array}$ & 16 & 47,62 & 20 & 61,90 & 25 & 76,19 & 27 & 80,95 & 22 & $66,67 \%$ \\
\hline 6 & $\begin{array}{l}\text { Menjawab } \\
\text { pertanyaan }\end{array}$ & 2 & 4,76 & 2 & 4,76 & 5 & 14,29 & 9 & 28,57 & 4 & $13,10 \%$ \\
\hline 7 & $\begin{array}{l}\text { Mengerjakan } \\
\text { tugas }\end{array}$ & 19 & 57,14 & 30 & 90,48 & 28 & 85,71 & 27 & 80,95 & 26 & $78,57 \%$ \\
\hline 8 & $\begin{array}{l}\text { Menyampaikan } \\
\text { pendapat }\end{array}$ & 0 & 0 & 3 & 9,52 & 2 & 4,76 & 6 & 19,05 & 3 & $8,33 \%$ \\
\hline 9 & $\begin{array}{l}\text { Terlibat membuat } \\
\text { kesimpulan }\end{array}$ & 2 & 4,76 & 2 & 4,76 & 3 & 9,52 & 2 & 4,76 & 2 & $5,95 \%$ \\
\hline 10 & $\begin{array}{l}\text { Mendemonstrasik } \\
\text { an tugas }\end{array}$ & 0 & 0 & 3 & 9,52 & 3 & 9,52 & 5 & 14,29 & 3 & $8,33 \%$ \\
\hline
\end{tabular}


2) Hasil Belajar

Setelah pelaksanaan tindakan kelas pada siklus I dengan dua kali pertemuan pemberian materi menggunakan model team games tournament, maka pertemuan keempat diadakan evaluasi untuk mengetahui hasil belajar siswa kelas XI TAV1 SMK Negeri 4 Gowa.

Setelah pemberian post-test pada siklus I, maka diperoleh skor hasil belajar Perencanaan dan Instalasi Sistem Audio Video berdasarkan analisis deskriptif pengaplikasian model TGT menunjukkan bahwa rata-rata siswa memperoleh nilai 57,15 dengan nilai terendah 25 dan nilai tertinggi 85. Sedangkan ketuntasan belajar Perencanaan dan Instalasi Sistem Audio Video dapat dilihat berdasarkan daya serap siswa terhadap materi yang diajarkan dikelompokkan dalam kategori tuntas dan tidak tuntas, maka diperoleh distribusi frekuensi dan persentase ketuntasan belajar Perencanaan dan Instalasi Sistem Audio Video pada Siklus I dapat dilihat pada Tabel dibawah ini.

Tabel 3. Distribusi Frekuensi dan Persentase Hasil Belajar Perencanaan dan Instalasi Sistem Audio Video Siswa Kelas XI TAV1 SMK Negeri 4 Gowa pada Tes Siklus I

\begin{tabular}{|c|c|c|c|}
\hline \multirow{2}{*}{ Kategori } & Interval & \multicolumn{2}{|c|}{ Siklus I } \\
\cline { 3 - 4 } & f & Persen (\%) \\
\hline $\begin{array}{c}\text { Sangat } \\
\text { Tinggi }\end{array}$ & $90-100$ & 0 & $0.00 \%$ \\
\hline Tinggi & $80-89$ & 3 & $9.09 \%$ \\
\hline Sedang & $65-79$ & 13 & $39.39 \%$ \\
\hline Rendah & $55-64$ & 3 & $9.09 \%$ \\
\hline $\begin{array}{c}\text { Sangat } \\
\text { Rendah }\end{array}$ & $0-54$ & 14 & $42.42 \%$ \\
\hline \multicolumn{2}{|c|}{ Jumlah } & $\mathbf{3 3}$ & $\mathbf{1 0 0 \%}$ \\
\hline
\end{tabular}

Tabel di atas menunjukkan bahwa dari 33 orang siswa XI TAV1 SMK Negeri 4 Gowa pada tes siklus I diketahui bahwa 14 orang siswa atau $42,42 \%$ berada pada kategori sangat rendah, 3 orang siswa atau 9,09\% berada pada kategori kategori rendah, 13 orang siswa atau 39,39\% berada pada kategori sedang, 3 orang siswa atau 9,09 \% berada pada kategori tinggi, dan tidak ada siswa yang masuk dalam kategori sangat tinggi. Data hasil belajar berdasarkan ketuntasan hasil belajar dapat dilihat pada tabel berikut ini.

Tabel 4. Ketuntasan Hasil Belajar Perencanaan dan Instalasi Sistem Audio Video Siswa pada Siklus I

\begin{tabular}{|c|c|c|c|}
\hline Skor & Kategori & Frekuensi & Persentase KKM Klasikal (\%) \\
\hline $75-100$ & Tuntas & 16 & $48,48 \%$ \\
\hline$<75$ & $\begin{array}{c}\text { Tidak } \\
\text { Tuntas }\end{array}$ & 17 & $51,52 \%$ \\
\hline
\end{tabular}

Tabel diatas menunjukkan bahwa jumlah siswa yang tidak tuntas hasil belajarnya 17 orang atau $51,52 \%$ dan siswa yang tuntas hasil belajarnya 16 orang atau 48,48\% yang telah mencapai KKM mata pelajaran Perencanaan dan Instalasi Sistem Audio Video yaitu 275 . Hal tersebut berarti bahwa pengaplikasian model Team Games Tournament pada siklus I belum mencapai KKM Klasikal yakni $85 \%$. 


\section{3) Analisis Refleksi Siklus I}

Data hasil tes yang dilakukan di akhir Siklus I menunjukkan bahwa ketuntasan belajar siswa kelas XI TAV 1 SMK Negeri 4 Gowa dalam memahami materi Perencanaan dan Instalasi Sistem Audio Video melalui model pembelajaran Team Games Tournament belum mencapai target indikator keberhasilan dalam penelitian yaitu hanya 48,48\% yang memperoleh nilai $\geq 75$ dari $85 \%$ yang ditargetkan secara klasikal. Sedangkan dari hasil observasi pada pelaksanaan tindakan Siklus I, ada beberapa kekurangan yang dilakukan oleh siswa yaitu:

a) Masih ada beberapa siswa yang tidak memperhatikan guru pada saat menyampaikan materi pelajaran.

b) Masih ada beberapa siswa yang tidak berdiskusi saat menyelesaikan masalah kelompok.

c) Masih banyak siswa yang kurang aktif dalam menerima pelajaran.

d) Masih kurangnya respon yang ditunjukkan ketika peneliti mengajukan pertanyaan.

\section{Deskripsi Hasil Siklus II}

Pelaksanaan tindakan siklus II dilakukan oleh guru Perencanaan dan Instalasi Sistem Audio Video.

1) Aktivitas Siswa

Data observasi aktivitas siswa diperoleh dari lembar observasi selama proses belajar mengajar berlangsung pada setiap pertemuan yang dilakukan oleh observer. Penilaian aktivitas siswa yang diamati sebanyak 10 komponen yang dapat dilihat pada tabel berikut.

Tabel 5. Hasil Observasi Aktivitas Siswa Pada Siklus II

\begin{tabular}{|c|l|c|c|c|c|c|c|c|c|c|c|}
\hline \multirow{2}{*}{ No } & \multirow{2}{*}{$\begin{array}{l}\text { Indikator yang } \\
\text { Diamati }\end{array}$} & \multicolumn{6}{|c|}{ Siklus II } & \multirow{2}{*}{$\begin{array}{c}\text { Rata- } \\
\text { rata }\end{array}$} & $\begin{array}{c}\text { Rata- } \\
\text { rata } \\
(\%)\end{array}$ \\
\cline { 2 - 13 } & \multicolumn{2}{|c|}{ Pert-1 } & \multicolumn{2}{|c|}{ Pert-2 } & \multicolumn{2}{|c|}{ Pert-3 } & \multicolumn{2}{|c|}{ Pert-4 } \\
\hline 1 & Hadir tepat waktu & 33 & 100 & 33 & 100 & 30 & 90,48 & 33 & 100 & 32 & $97,62 \%$ \\
\hline 2 & $\begin{array}{l}\text { Memperhatikan } \\
\text { guru menjelaskan }\end{array}$ & 30 & 90,48 & 27 & 80,95 & 28 & 85,71 & 31 & 95,24 & 29 & $88,10 \%$ \\
\hline 3 & Bertanya & 13 & 38,10 & 13 & 38,10 & 11 & 33,33 & 13 & 38,10 & 12 & $36,90 \%$ \\
\hline 4 & $\begin{array}{l}\text { Aktif dalam } \\
\text { diskusi }\end{array}$ & 20 & 61,90 & 24 & 71,43 & 24 & 71,43 & 28 & 85,71 & 24 & $72,62 \%$ \\
\hline 5 & $\begin{array}{l}\text { Menghargai } \\
\text { pendapat }\end{array}$ & 30 & 90,48 & 33 & 100 & 30 & 90,48 & 33 & 100 & 31 & $95,24 \%$ \\
\hline 6 & $\begin{array}{l}\text { Menjawab } \\
\text { pertanyaan }\end{array}$ & 13 & 38,10 & 13 & 38,10 & 9 & 28,57 & 13 & 38,10 & 12 & $35,72 \%$ \\
\hline 7 & $\begin{array}{l}\text { Mengerjakan } \\
\text { tugas }\end{array}$ & 31 & 95,24 & 33 & 100 & 30 & 90,48 & 33 & 100 & 32 & $96,43 \%$ \\
\hline 8 & $\begin{array}{l}\text { Menyampaikan } \\
\text { pendapat }\end{array}$ & 8 & 23,81 & 13 & 38,10 & 13 & 38,10 & 16 & 47,62 & 12 & $36,91 \%$ \\
\hline 9 & $\begin{array}{l}\text { Terlibat membuat } \\
\text { kesimpulan }\end{array}$ & 3 & 9,52 & 6 & 19,05 & 6 & 19,05 & 8 & 23,81 & 6 & $17,86 \%$ \\
\hline 10 & $\begin{array}{l}\text { Mendemonstrasik } \\
\text { an tugas }\end{array}$ & 5 & 14,29 & 3 & 9,52 & 6 & 19,05 & 9 & 28,57 & 6 & $17,86 \%$ \\
\hline
\end{tabular}




\section{2) Hasil Belajar}

Setelah pelaksanaan tindakan kelas pada siklus II, maka di adakan post-test untuk mengetahui hasil belajar siswa SMK Negeri 4 Gowa pada mata pelajaran Perencanaan dan Instalasi Sistem Audio Video dengan menerapkan model Team Games Tournament. Setelah pemberian evaluasi pada siklus II, maka diperoleh skor hasil belajar Perencanaan dan Instalasi Sistem Audio Video menggunakan model team games tournament berdasarkan analisis deskriptif menunjukkan bahwa rata-rata siswa memperoleh nilai 78,82 dengan nilai terendah 55 dan nilai tertinggi 100. Sedangkan ketuntasan belajar Perencanaan dan Instalasi Sistem Audio Video dapat dilihat berdasarkan daya serap siswa terhadap materi yang diajarkan dikelompokkan dalam kategori tuntas dan tidak tuntas, maka diperoleh distribusi frekuensi dan persentase ketuntasan belajar Perencanaan dan Instalasi Sistem Audio Video pada Siklus I dapat dilihat pada Tabel berikut:

Tabel 6. Distribusi Frekuensi dan Persentase Hasil Belajar Perencanaan dan Instalasi Sistem Audio Video Siswa pada Siklus II

\begin{tabular}{|c|c|c|c|}
\hline \multirow{2}{*}{ Kategori } & \multirow{2}{*}{ Interval } & \multicolumn{2}{|c|}{ Siklus II } \\
\cline { 3 - 4 } & & $\mathbf{f}$ & Persen (\%) \\
\hline Sangat Tinggi & $90-100$ & 8 & $24.24 \%$ \\
\hline Tinggi & $80-89$ & 9 & $27.27 \%$ \\
\hline Sedang & $65-79$ & 13 & $39.39 \%$ \\
\hline Rendah & $55-64$ & 3 & $9.09 \%$ \\
\hline Sangat Rendah & $0-54$ & 0 & $0.00 \%$ \\
\hline \multicolumn{2}{|r|}{ Jumlah } & $\mathbf{3 3}$ & $\mathbf{1 0 0 \%}$ \\
\hline
\end{tabular}

Tabel diatas menunjukkan bahwa dari 33 siswa XI TAV1 SMK Negeri 4 Gowa pada tes siklus II diketahui bahwa tidak ada siswa yang masuk dalam kategori sangat rendah, 3 orang siswa atau 9,09\% berada pada kategori rendah, 13 orang siswa atau 39,39\% berada pada kategori sedang, 9 orang siswa atau 27,27 \% berada pada kategori tinggi, dan 8 orang siswa atau $24,24 \%$ berada pada kategori sangat tinggi. Data hasil belajar berdasarkan ketuntasan hasil belajar dapat dilihat pada tabel berikut ini.

Tabel 7. Ketuntasan Hasil Belajar Perencanaan dan Instalasi Sistem Audio Video Siswa Kelas XI TAV1 SMK Negeri 4 Gowa pada Tes Siklus II

\begin{tabular}{|c|c|c|c|}
\hline Skor & Kategori & Frekuensi & Persentase KKM Klasikal (\%) \\
\hline $75-100$ & Tuntas & 30 & $90,91 \%$ \\
\hline$<70$ & $\begin{array}{c}\text { Tidak } \\
\text { Tuntas }\end{array}$ & 3 & $9,09 \%$ \\
\hline
\end{tabular}

Tabel diatas menunjukkan bahwa jumlah siswa yang tidak tuntas hasil belajarnya 3 orang atau 9,09\% dan siswa yang tuntas hasil belajarnya 30 orang atau 90,91\% yang telah mencapai KKM mata pelajaran Perencanaan dan Instalasi Sistem Audio Video yaitu $\geq 75$. Hal tersebut berarti bahwa pengaplikasian model Team Games Tournament pada siklus II sudah melampaui KKM Klasikal yakni $85 \%$.

Berdasarkan analisis data secara kuantitatif dengan menggunakan statistik deskriptif diperoleh nilai rata-rata siswa 47,15 pada tes awal, nilai rata-rata siswa 57,15 pada Siklus I dan nilai rata-rata siswa 78,82 pada Siklus II. Dilihat dari tingkat ketuntasan belajar siswa 
pada tes awal sebanyak 6 dari 33 orang siswa yang berada pada kategori tuntas, Siklus I sebanyak 16 dari 33 orang siswa yang berada pada kategori tuntas, dan pada Siklus II meningkat menjadi 30 dari 33 orang siswa yang berada pada kategori tuntas.

Hal ini menunjukkan adanya peningkatan hasil belajar pada Siklus II baik dalam pelaksanaan pembelajaran, keaktifan siswa dalam pembelajaran, maupun pencapaian tujuan dan ketuntasan belajar dengan menerapkan model TGT. Walaupun masih ada siswa yang tidak tuntas setelah diadakan refleksi, ketidaktuntasan tersebut disebabkan karena ada siswa yang tidak bisa mengikuti proses belajar mengajar karena sakit sehingga ketinggalan materi dan keterbatasan kemampuan siswa dalam menyelesaikan permasalahan yang diberikan walaupun telah mendapat bimbingan dari peneliti.

Peneliti mengajarkan Perencanaan dan Instalasi Sistem Audio Video pada siswa XI TAV1 SMK Negeri 4 Gowa dengan efektif merupakan tantangan yang cukup besar. Peneliti tidak sekedar dituntut untuk mencapai kualitas pembelajaran yang baik berdasarkan pada rata-rata nilai Perencanaan dan Instalasi Sistem Audio Video siswa pada setiap pemberian tes, tetapi juga dituntut untuk mengelolah pembelajaran sehingga semua siswa memberikan respon positif terhadap pembelajaran yang dilaksanakan.

Berdasarkan hasil analisis observasi pada Siklus I dan Siklus II menunjukkan adanya perubahan tingkah laku pada siswa, di mana siswa lebih memiliki rasa percaya diri. Sikap ini mempengaruhi mental siswa sehingga dapat mendorong keinginan siswa untuk berusaha menemukan solusi dari setiap masalah yang ditemui dalam kelompok belajar. Perubahan tingkah laku tersebut dapat pula melatih siswa mengerjakan latihan sehingga meningkatkan keterampilan, keaktifan, dan konsentrasi yang berdampak pada peningkatan hasil belajar yang dilihat dari ketuntasan siswa dari Sikus I sampai Siklus II. Hal ini menunjukkan bahwa pengaplikasian model $T G T$ dalam pembelajaran Perencanaan dan Instalasi Sistem Audio Video kelas XI TAV1 SMK Negeri 4 Gowa berhasil. Hal ini sesuai dengan pernyataan bahwa model TGT merupakan salah satu metode pembelajaran dengan konsep pembelajaran yang efektif dan menyenangkan, memberikan kesempatan bagi siswa untuk belajar mengembangkan kemampuan keterampilan belajarnya termasuk mengembangkan kemampuan berpikir kreatif serta memadukan berbagai sugesti positif dan interaksinya dengan lingkungan dan teman-temannya yang dapat mempengaruhi proses dan hasil belajar siswa.

\section{Kesimpulan}

Berdasarkan hasil penelitian dan pembahasan maka dapat disimpulkan bahwa pengaplikasian model TGT terhadap mata pelajaran Perencanaan dan Instalasi Sistem Audio Video dapat meningkatkan hasil belajar siswa kelas XI TAV1 SMK Negeri 4 Gowa, hal ini dapat dilihat dari peningkatan persentase dari siklus I ke siklus II. Dari siklus I dengan persentase $48,48 \%$ atau 16 dari 33 orang siswa yang dinyatakan tuntas belajarnya dan siklus II dengan persentase $90,91 \%$ atau 30 dari 33 orang siswa yang dinyatakan tuntas belajarnya. Peningkatan dari siklus I ke siklus II adalah 42,43\%. Berdasarkan hasil observasi aktivitas, keaktifan siswa juga meningkat pada pembelajaran Perencanaan dan Instalasi Sistem Audio Video dengan menerapkan model pembelajaran $T G T$.

\section{Saran}

Berdasarkan hasil yang diperoleh dalam penelitian ini maka beberapa hal yang disarankan antara lain sebagai berikut: (1) Diharapkan kepada guru mata pelajaran Perencanaan dan Instalasi Sistem Audio Video, lebih kreatif dan inovatif dalam memilih 
model pembelajaran yang relevan dengan materi untuk menciptakan lingkungan belajar yang lebih menyenangkan siswa. (2) Diharapkan kepada peneliti lain dalam bidang kependidikan supaya dapat meneliti lebih lanjut tentang model pembelajaran yang efektif dan efisien untuk mengatasi kesulitan belajar siswa.

\section{Daftar Pustaka}

Ajie Bella Fajar. (2013). Peningkatan Kualitas Pembelajaran IPA Melalui Model Problem Based Instruction (PBI) Pada Siswa Kelas III SDN Gunungpati 02. Skripsi. Semarang: Universitas Negeri Semarang.

Anni, Catharina T dkk. (2007). Psikologi Belajar. Semarang: UNNES Press

Arikunto, Suharsimi. (2015). Dasar-Dasar Evaluasi Pendidikan. Jakarta: Bumi Aksara

Bambang Sumatri. (2014). Peningkatan Kualitas Pembelajaran PKn Melalui Model Pembelajaran Kooperatif Tipe Team Games Tournament (TGT),(Online), vol.13, no. 1, (https://core.ac.uk/download/files/478/12350758.pdf, di akses 5 maret 2015).

Fajuri, F. (2019). Penerapan Pendekatan Cooperative Learning Tipe Jigsaw dalam Upaya Meningkatkan Aktivitas dan Hasil Belajar Peserta Didik Kelas I SD Negeri 27 Ampenan. Jurnal Paedagogy, 6(1), 20-26. doi:https://doi.org/10.33394/jp.v6i1.2526

Isnaizakiya. 2015. Desain Pembelajaran, Perencanaan Pembelajaran dan Kurikulum, (online), (https://isnaizakiya29.wordpress.com/2015/05/24/ desain-pembelajaranperencanaan-pembelajaran-dan-kurikulum/, di akses 11 maret 2015).

Juwairiah. (2008). Profesionalisme Guru Melalui Lesson Study, (online), (http://sumut.kemenag.go.id/file/file/TULISANPENGAJAR/akzh1343183231.pdf, diakses 5 maret 2015).

Nur, Mohammad. (2011). Model Pembelajaran Berdasarkan Masalah. Surabaya: UNESA

Pupuh Fathurrohman \& Sobry Sutikno. 2010. Strategi Belajar Mengajar. Bandung: Refika Aditama.

Rosidha, A. (2020). Peningkatan Aktivitas dan Hasil Belajar Siswa pada Mata Pelajaran Biologi Melalui Model Pembelajaran Make and Match Berbasis Media Karu Pintar. Jurnal Paedagogy, 7(4), 393-401. doi:https://doi.org/10.33394/jp.v7i4.2946

Rusman. (2012). Model-Model Pembelajaran. Jakarta: Rajawali Pers.

Setiarini, A. (2016). Meningkatkan Motivasi dan Hasil Belajar Peserta Didik dengan Mengoptimalkan Penerapan Pendekatan Saintifik Strategi Discovery Learning dan Metode Diskusi di SDN Model Mataram. Jurnal Kependidikan: Jurnal Hasil Penelitian dan Kajian Kepustakaan di Bidang Pendidikan, Pengajaran dan Pembelajaran, 2(1). doi:https://doi.org/10.33394/jk.v2i1.390

Sri Pertiwi. (2011). Efektivitas Model Pembelajaran Kooperatif Tipe Team Games Tournament (TGT) dan Jigsaw Pada Prestasi Belajar Matematika Ditinjau dari Motivasi Belajar Siswa SMP Di Kabupaten Blora. Tesis tidak diterbitkan. Surakarta: Program Pascasarjana Universitas Sebelas Maret.

Sugandi, Achmad, dkk. (2008). Teori Pembelajaran. Semarang : UPT MKK UNNES

Sudjana. (2004). Media Pengajaran. Jakarta: Algensindo

Sudjana, Nana. (2006). Penilaian Hasil Proses Belajar Mengajar. Bandung : Remaja Rosda Karya.

Sudrajat, Akhmad. (2008). Lesson Study Untuk Meningkatkan Pembelajaran, (Online), (https://akhmadsudrajat.wordpress.com/2008/02/22/lesson-study-untukmeningkatkan-pembelajaran/, diakses 27 Februari 2015). 
Supardi. (2015). Penilaian Autentik Pembelajaran Afektif, Kognitif, Dan Psikomotor (Konsep Dan Aplikasi). Jakarta: Rajawali Pers.

Suryani, E. (2018). Meningkatkan Hasil Belajar Ekonomi Melalui Pembelajaran Kooperatif Metode Think Pair Share pada Siswa Kelas XI SMA Negeri 3 Mataram. Jurnal Kependidikan: Jurnal Hasil Penelitian dan Kajian Kepustakaan di Bidang Pendidikan, Pengajaran dan Pembelajaran, 4(2), 141-150. doi:https://doi.org/10.33394/jk.v4i2.1122

Trianto. (2010). Mendesain Model Pembelajaran Inovatif-Progresif: Konsep, Landasan, dan Implementasinya pada Kurikulum Tingkat Satuan Pendidikan (KTSP). Jakarta: Kencana Prenada Media Group.

Wati Melina. (2012). Konsep dasar desain pembelajaran, (online), (watimelinaymail.blogspot.co.id/2010/12/konsep-dasar-desain pembelajaran, di akses 11 maret 2015)

Wirejati, W. (2019). Peningkatan Mutu Hasil Belajar Siswa Kelas IX.A SMPN 7 Pujut pada Materi Sistem Ekskresi Melalui Pembelajaran Kooperatif Tipe Student Teams Achievement Divisions. Jurnal Paedagogy, 6(2), 59-65. doi:https://doi.org/10.33394/jp.v6i2.2532

Yuliati, G. (2018). Peningkatan Hasil Belajar Matematika Siswa Kelas XI IPA 3 SMA Negeri 1 Batukliang Melalui Penggunaan Model Pembelajaran Student Teams Achievement Division. Jurnal Kependidikan: Jurnal Hasil Penelitian dan Kajian Kepustakaan di Bidang Pendidikan, Pengajaran dan Pembelajaran, 4(1), 31-40. doi:https://doi.org/10.33394/jk.v4i1.899 